\title{
Markets, Exchange and the Extreme
}

\author{
Cornelius G. Buttimer and Donncha Kavanagh \\ Department of Modern Irish and Department of Management and Marketing \\ University College Cork, Ireland
}

\begin{abstract}
published in Stephen Brown, et al. (ed.) (1996), Marketing Apocalypse: Eschatology, Escapology and the Illusion of the End, Routledge, London, pp. 145-170.
\end{abstract}

\section{Beyond the End of Marketing}

Marketing is contemplating its End, in at least two senses of the word (Brown 1993b; Brownlie and Saren 1992; 1995). Ruminations on its demise are unsurprising, since crisis and images of death are primal parts of our attempt at making sense of the world (Kermode 1967). Such apocalyptic visions occur with particular sharpness at fin de siècle times, not to mention towards the close of a millennium, which might explain the recent flurry of announcements of the End: of the world (Meadows et al. 1972), industrial society (Touraine 1974), capitalism (Lash and Urry 1987), the social (Baudrillard 1988), history (Fukuyama 1989), and work (Rifkin 1995). Latter-day predictions of marketing's imminent downfall can be seen as prototypical of this phenomenon. Moreover, these declarations are singularly characteristic of modernity, with its passion for re-invention, for new Ends and new Beginnings. But histrionic proclamations of the End often fail to deliver on their promise of finality: for beneath the cloak of eschatological language is modernity's ongoing teleological project of rampantly re-visioning the future. We prefer, therefore, to demur from the current discussion on the End of Marketing. Rather, we shall focus, in this chapter, on the End in Marketing. Here, we interpret End as meaning limit, extreme or margin, and, in particular, the extremes of the human condition. We posit that these extremes are pervasive in the market-place, which we view as a site where human limitations can be quite overtly articulated. This paper, then, contributes to our understanding of market phenomena through a study of the complex inter-relationship between markets, exchange and the extreme. 
This interest in Ends is, in effect, an interest in boundaries, and this awakens us to some of the philosophical and methodological borders within marketing itself. Marketing's recent concern with matters apocalyptic also highlights issues and edges that have been largely ignored within the field, such as the metaphysical, eternity and time (Kavanagh 1994). With regard to the latter, we agree with Fullerton's (1987) assertion that marketing is paradigmatically averse to history, existing in a temporal dimension best described as permanently present. In what follows we seek to transcend this temporal boundary. We also see value in breaching disciplinary constraints and merging a range of empirical data and theoretical viewpoints. Hence, we have deliberately embraced a pastiche approach in our research. We believe that this eclecticism is appropriate and even necessary if we are to deepen our appreciation of markets and marketing activity which, in our opinion, is the marketing scholar's ultimate goal or end.

\section{Exegesis}

Our work is based on a hermeneutic study of texts and visual records that pertain particularly, although not exclusively, to pre-modern markets. We attempt to make both categories of evidence as comprehensive as space constraints permit. We take the reader from comparatively recent testimony to the medieval period, the classical world and forwards again towards modernity; voyage across north-west European culture, the Mediterranean region, North America and the East; and sample the riches of art-work, poetry, saga and other forms of prose narrative, derived from literate societies or recorded latterly during ethnographic field-work. The communities delved into vary from aristocratic to multi-class to peasant cultures, and there is corresponding variation in the tenor of the events described.

\section{Picturing the Market}

Barrell (1980) has noted that commercial exchange and work, which occupy such a major place in individual and collective life, are very under-represented in art. However, if there are relatively few paintings of pre-modern markets, what is there is challenging, especially 
the output of artists such as Peter Bruegel in the sixteenth century. Bruegel's The Fight between Carnival and Lent (figure 1a), painted in 1559, portrays the festive in the market square of a late-medieval town. Significantly, the piece depicts a commercial transaction - a woman buying fish (figure 1b) - at the very centre of the image, the locus around which the picture's other features are arranged. Circumscribing this interchange is a catalogue of extremes, including inversions (women taking the role of cart-horses), grotesque realism (protuberant, incomplete, over- and under-sized depictions of the body), dissimulation (cheating, masks and make-believe), music, gambling, and dance. Around the margins of the painting a procession of sombre, dark characters intrudes, highlighting the conflict between the profanity of the carnival and the sanctity of Lent. Such Bruegelian perspectives on the market also occur in later periods, like in the nineteenth-century illustration of Donnybrook Fair (figure 2), a well-known popular gathering held near Dublin until its decline towards the end of the last century (Ó Maitiú 1995), where we can again witness the intermixing of the commercial and the carnivalesque.

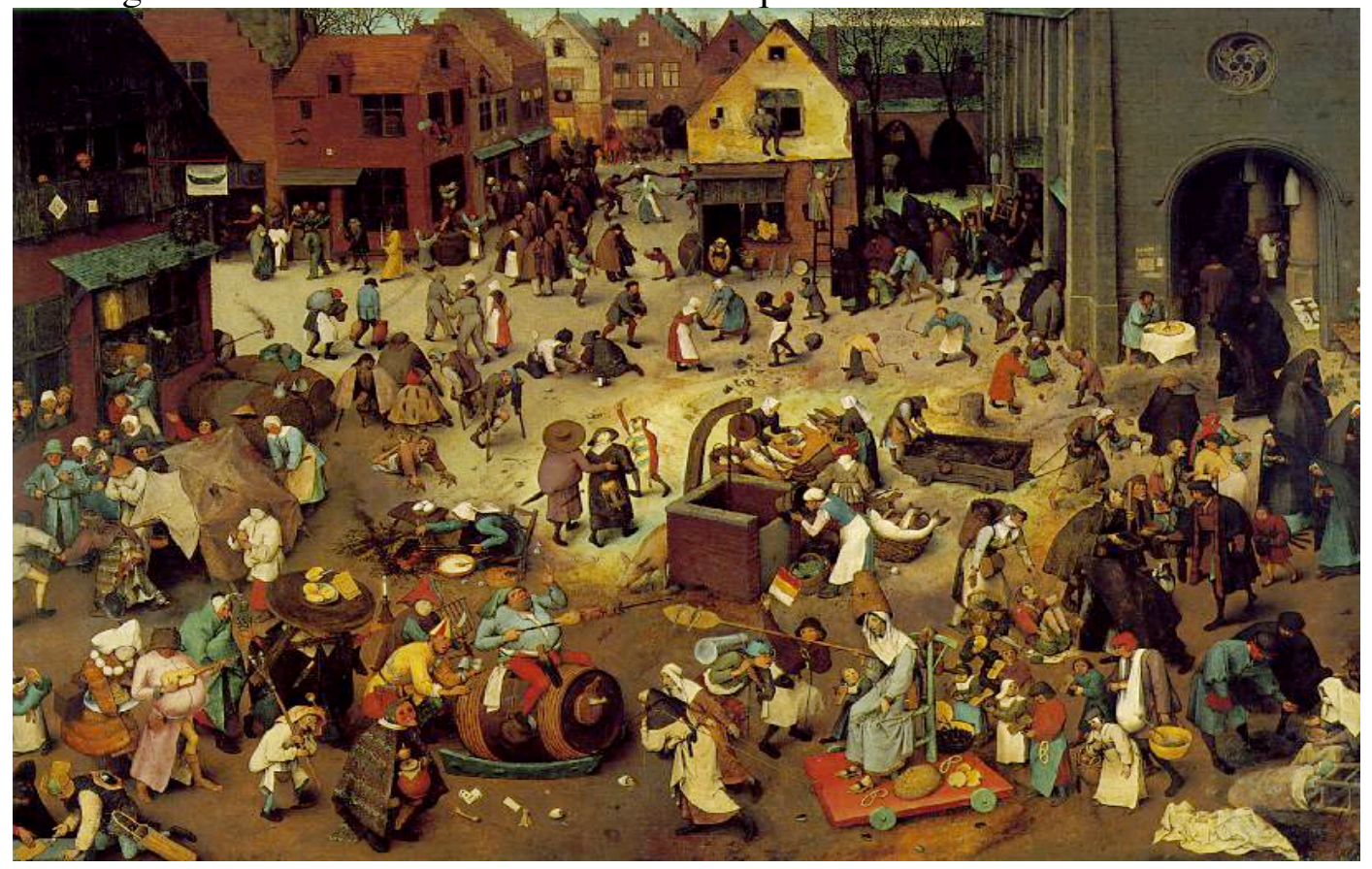

Figure 1a. Peter Bruegel, The Fight between Carnival and Lent (1559), Kunsthistorisches Museum, Vienna, with permission. 


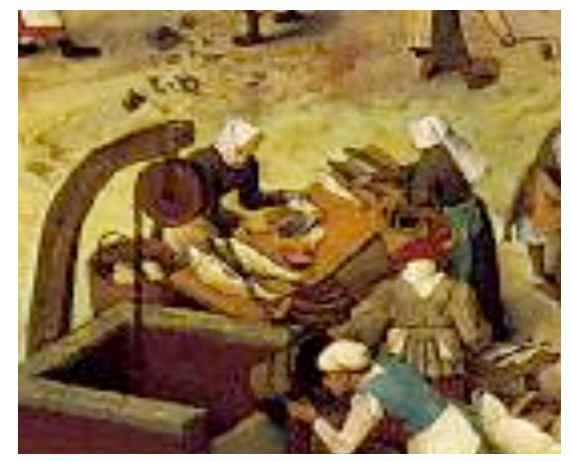

Figure 1b. The Fight between Carnival and Lent. Detail.

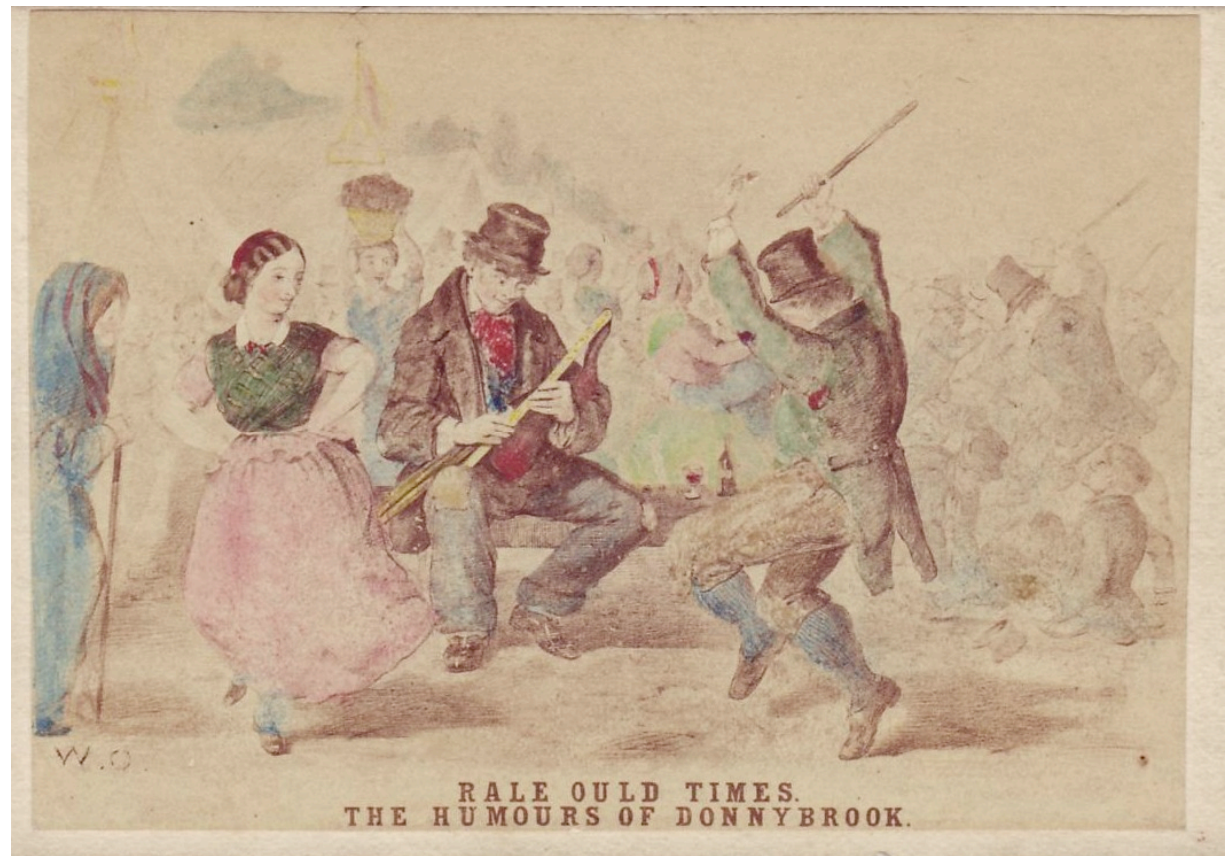

Figure 2. Donnybrook Fair in the Year 1830.

\section{Writing the Market}

Traversing media, we see a similar expression of tumult and turbulence in the world of poetry. These features are well expressed in Tuairisc Amhailt Uí Iartáin, a late eighteenthcentury Gaelic verse composition from a south-east Ireland manuscript, offering a panorama of a localised, village or small-town fair in its sixty-four lines (Buttimer 1992). Prices seem excessive in relation to the livestock on offer; commodities such as food and drink are readily available for consumption on the spot; these combine with music, dancing and sporting to 
produce an atmosphere of noisy abandon: youths chase and seduce girls, one sees pickpocketing, faction-fighting and drunken disputation, in which conditions animals go astray. The following excerpts convey, in English translation, the atmosphere of the original rhythmical Gaelic:

... a mangy ewe six and six, a hedgehog-sized pig thrice sixpence ...

There was play below by the old road valley, violin and pipe at the wood-sorrel fence, with rough dancing killing beatles, the lower orders' old shoes squeaking, running contests at the shamrock field and chancers and gamblers crying foul ... Honor was chasing George Cusack because he uncovered her knee and her hem as she lay on her rear in a nettle-bush recess ... Pick-pockets there were chased and run after, there was fighting, striking and commotion... At the custom's gap jackets were opened, shouts of lies, falsehood and exclamation, oaths sworn without warning or reservation.

Oath-taking is heard at the tolls as dealers conceal the value of their purchases from the customs authorities. The last laugh is on the individual reporting the various incidents. In his distraction he has failed to sell his wares and is left impoverished, unable to obtain a consoling draught to "wet his old throat". Throughout this relatively nonchalant piece, the persona reveals an attitude of bemusement on his part at his own foibles as well as those of his fellow human beings. 
If nonchalance is the dominant feature of this eighteenth-century fair, then crisis and catastrophe feature more prominently in an earlier description of an oenach, which is the Old Irish term for an assembly or fair. The source here is the ninth-century saga Noinden Ulad, 'The Debility of the Ulstermen' (Hull 1968), which forms part of a major cycle of stories about the pre-Christian heroic province of Ulster in north-eastern Ireland (Thurneysen 1921). Noínden Ulad describes significant failure of a kind also evident in other Ulster legends like the famous Deirdre story later re-worked by W. B. Yeats and J. M. Synge (Buttimer 1994-95). The 'Debility of the Ulstermen' tells how a woman, Macha, inflicted a crippling weakness on the fighting men of Ulster leading them to lose their energy in times of crisis, such as an invasion of their territory. Macha's husband, Crunnchu, a wealthy commoner, boasted of her superior speed at an oenach, presided over by the king, of whom it was stated that no horses were swifter than his. Although pregnant, the woman was obliged to race against the ruler's steeds to prove the assertion or else see Crunnchu killed. Having outpaced the animals she gave birth to twins in the following dramatic encounter:

. . ba sisi boí urtharsna ara cinn i cinn na láithre. La sodain at-racht a screit nesi ar tíachra in galair. Ro-glé Día dí fo cét-óir, ocus berid mac 7 ingin i n-óentairbirt. Amail ro-cólatar in slúag uile a screit inna banscáile, fos-ceird fóo combo inann nert dóib uli 7 in banscál boí isin galur. . .

... at the end of the course she was across in front of [the horses]. Thereupon a scream arose from her on account of the pain of the travail. Forthwith God cleared it away for her, and she bore a boy and a girl at one birth. As soon as all the people heard the scream of the woman, it laid them low so that the strength of all of them was the same as [that of] the woman who was in travail.

Macha's capacity to impose so powerful a sanction on Ulster's warriors probably reflects divine attributes associated with her elsewhere in the literature. Nonetheless the story 
employs the vocabulary of everyday experience rather than that of mythology to explore its major theme. The story shows that Macha adhered strictly to the requirements of domestic propriety when establishing herself in Crunnchu's homestead. She also reminded the messengers, who came to compel her to attend the oenach, of the legal rights to delay pregnant women were allowed in complying with a request (Kelly 1988). She was nonetheless constrained to attend the event. The violation of her dignity suggests the saga is concerned with an inability to maintain the appropriate distinction between life's private and public spheres (Buttimer 1995), a dilemma recalling a critical preoccupation of Sophocles' Antigone (Steiner 1984). Tellingly, the oenach is the locus of this confusion of categories and the resultant cataclysmic impact on the Ulster community.

Moving across cultures, we see that the market-place and an apocalyptic moment coincide in another major early civilization, that of Israel at the commencement of the Christian period. We refer to the famous episode of Christ driving the traders from the temple. This is probably the only occasion one witnesses Jesus engage in an act of physical aggression in the Gospels. Indeed the outburst's physicality is emphasised in later medieval and early modern iconographic portraits of the scene by such artists as Ghiberti, El Greco and Rembrandt (Suchaux and Pastoureau 1994 p. 243). Their art-work is effectively an interpretation of passages like the following in the Gospel of St John (2:13-17), cited here from the King James' version:

(13) And the Jews' passover was at hand, and Jesus went up to Jerusalem, (14) And found in the temple those that sold oxen and sheep and doves, and the changers of money sitting: (15) And when he had made a scourge of small cords, he drove them all out of the temple, and the sheep, and the oxen; and poured out the changers' money, and overthrew the tables; (16) And said unto them that sold doves, Take these things hence; make not my Father's house an house of merchandise. (17) And his disciples remembered that it was written, The zeal of thine house hath eaten me up. 
Significantly, the market episode is at the heart of an apocalyptic event. It reflects the longstanding tension between Jesus and the Pharisees on matters of mendacity (Mt 11, 12, 15, 19, 20, Mk 2, 7, Lk 5, 7, 11), and brings relations between Christ and the religious establishment to a new level of tension, a debate that continues in the temple after his frenzy (Mt 22, 23, Mk 11, 12, Lk 20). More importantly, this is the incident that ultimately triggers the Pharisees will to suppress him, which, in turn, is the fulfilment of Christ's predictions of his own death and the symbolic destruction of the temple which will later be re-embodied in himself (Mt 12:6, 26:61, 27:40). It is ironic that the same clergy are not slow to exploit the market for their own ends: scribes and pharisees, who are said to crave places of honour at feasts and the best seats in the synagogues, seemingly go there to receive public adulation (Mt 23:7, Mk 12:38, Lk 20:46). At the same time, the market is seen as a likely source of contamination; it is stated of clerics that when they come from the market-place they do not eat unless they purify themselves (Mk 7.4). The importance of the market episode is further highlighted by its narrative location: in three of the gospels it is at the start of the death and resurrection sequence, while in John's gospel the equivalent incident is prominently placed, out of the dominant narrative order, at the start of his public life (Powell 1990 pp. 36-38).

The intensity of Christ's temple outrage contrasts with the relative calm with which matters of commerce are dealt with elsewhere in the Gospels. It is clear that references to various types of exchange need not necessarily be so emotionally charged. Trade is clearly a facet of daily life: the statement about paying Caesar his dues (Mt 22:21, Mk 12:14) appears to be an acknowledgement of public finances, with advice to tax-collectors to take no more than is appointed to them ( $\operatorname{Lk} 3: 13)$. Even if the highest values transcend quantification (the lilies of the field are better clad than Solomon because of God's will (Mt 6:28-29)), Jesus frequently uses parables (Bailey and Vander Broek 1992) with a mercantile dimension to illustrate in practice what constitutes acceptable or unacceptable behaviour towards the divine, such as in the model of proper stewardship of an estate (Lk 16). It is interesting to observe that the story of Christ's troubled entry into the temple is preceded by a parable on a nobleman's just 
chastisement of his subjects for failure to manage correctly his and their financial affairs (Lk 19:11-17)

Subsequent events in place and time, which can only be mentioned here in passing, conjoin certain of the characteristics noted in our initial examples. Thus the municipal authorities sponsored a race for prostitutes on the feast day of St Mary Magdalene (22 July) at the fair in the Languedoc town of Beaucaire during the fourteen-hundreds (Otis 1985 pp.10 and 71). In the present century, Balinese cockfights, with their elaborate, symbolic wagering systems, coincide and interact with local markets (Geertz 1971 pp. 32-33, note 18). Bauman has similarly described how dog owners come to engage in an interchange of wits and words, in "creative exaggeration" and downright lying, at a popular dog trading fair (dating from the seventeenth century and still active) in the town of Canton, south of Dallas, Texas (Bauman 1986 pp. 11-32, 117-27).

\section{The End in the Market: Some Perspectives}

These various examples reveal a connection between exchange and extreme behaviour of all sorts: the inversions and carnivalesque in Bruegel's painting, the falsehoods of the hound fair, the rage of Jesus as he drove the traders from the temple, the race between Macha and the steeds in the ninth-century saga, excessive consumption of food and drink, displays of the diseased and deformed, noise and music, varieties of dissimulation, inversions, profanity, prostitution, cheating, stealing, fighting, gaming and the suspension of other social mores. What is striking is the range and collocation of this conduct. For us, it is ultimately of no import that the behaviour can be construed as foolish, irrational, deviant, immoral or criminal; rather it is significant because it is extreme. More arresting is the possibility that the market is a primary forum where extremes of human experience are manifest. This, then, is why we say that the End is in the market, since the market is a site where conduct that is reaching the limits of comprehension is concentrated. We have also used the term 
madness (Buttimer and Kavanagh 1995) to describe such behaviour, for madness may be construed as that which is beyond theory, beyond knowledge, beyond reason: the mad are deranged, past the limits of classification and comprehension. In Foucault's words:

Madness has become man's possibility of abolishing both man and the world and even those images that challenge the world and deforms man. It is, far beyond dreams, beyond the nightmare of bestiality, the last recourse: the end and the beginning of everything.

(1967 p. 281)

Foucault did not shirk the paradoxical task of attempting to describe what he regarded as the undefinable. Neither have others. In the following section we search through literatures and domains that might offer a satisfactory account of the madness of markets. We review etymology, economics, psychiatry and psychoanalysis, Marxist social theory, the sociology of deviance, anthropology, ethnology and the works of writers such as Nietzsche and Canetti. Each field brings a greater or lesser potential for understanding the connection between market exchange and the extreme. We have sought to present, in condensed form, these primary insights, and have also, where necessary, delineated the perceptible lacunae. We follow this investigation by drawing on these and other literatures to present our own conceptualisation of the market.

\section{Etymology}

Etymology provides us with a first linkage between market and madness, suggesting that extremes were widely recognised as cognate elements of exchange, even in ancient times. For example, medieval glossators associate the Old Irish term oenach with the Greek word agón, which also denotes an assembly held for trials and contests (see Huizinga (1955 pp. 30-1)). The extreme dimension is arguably clearer in its derivative, the verb agónió which means 'to be in agony'. Similarly, an early link between the market and dissimulation is evidenced by the fact that Mercury, the god of trade (and source of the word merchant), is 
also the king of thieves. However, the resonances of these terms have not been systematically exploited, even by students of the early Greek economy, who tend to focus more on issues like trade (Finley 1982) rather than the topic in question here.

\section{Psychiatry and Psychoanalysis}

Other fields have recognised the register of early words, such as psyche in the twin fields of psychiatry and psychoanalysis. These two disciplines have focused on extreme or mad behaviour since their inception, but they provide, from our perspective, a somewhat limited view of madness: psychiatry sees it as a form of deficiency, while the psychoanalytic outlook is that madness is a manifestation of a primitive, infantile state of mind caused by a defect of the ego. Sass (1992 pp. 16-21) has recently provided a powerful critique of both positions, arguing that they have each constructed the mad as "inferior" and oversimplified the phenomena they purport to explain. More important for present purposes, however, is the apparent absence of any sustained theory in either field linking exchange and the extreme. Hence, despite the scale of both literatures, they would seem to contribute little to our study.

\section{Economics}

Classical micro-economic theory provides one explanation: namely, 'irrational' behaviour can be rationalised if analysed using an alternative logic. For example, giving away money might be regarded as mad or irrational, but economics can account for such altruism by arguing that one cannot pre-ordain utility, and, therefore, if giving money away is considered useful by an individual, such an activity must be deemed to be rational. But by appealing to self-serving concepts such as rationality and utility, economic theory ultimately loses its explanatory power on a tautological merry-go-round. If every action may conceivably have some rational explanation, the term rationality ends up meaning nothing. This is one reason why it has been argued that conventional economic wisdom has presented so few insights into 'primitive economies' and phenomena like the ritual gift-giving or potlatch of some Indian tribes (Dalton 1968). Furthermore, economic theory makes no meaningful distinction between extreme and irrational behaviour. Extreme behaviour, as we understand it, is not 
necessarily irrational; rather it is extreme in the particular context where it is manifest. Indeed economics has little real visualisation of the extreme, preferring instead to see the market as essentially stable and at, or close to, 'equilibrium'. In contrast, the markets we have described are sites in which factors that are far from equilibrium - extremes - oppose and interweave with one another. Similarly, the Frankfurt School critique - that consumer irrationality is caused by the manipulative character of marketing and advertising - seems inadequate, because it is a thesis of irrationality rather than of extreme behaviour.

\section{Marx}

Marx ((1867) 1954) was probably the first writer to envisage an overlap between commercial exchange and extreme conduct when he developed his theory of alienation. In this he posited that such behaviour arises as a response to a sense of alienation which in turn is caused by the characteristics of modern capitalist markets and society. While Marx identified a series of causes for this development - such as the structural nature of modern society, industrialisation, the loss of community, the division of labour, technological change, increasing rationalization, and the ownership of property - we shall focus solely on the role played by market exchange in his argument.

Central to Marx's thesis was his view that human identity is created through productive and creative activity. In his words, man, by "acting on the external world and changing it . . at the same time changes his own nature" (Marx (1867) 1954 p. 177). He further posited that capitalist markets are characterised by a process through which the products of human labour are reduced to abstract "exchange values". Capitalist markets, therefore, are a great circulating web of transubstantiating commodities and money in which workers "appropriate the produce of the labour of others by alienating that of their own labour" (Marx (1867) 1954 pp. 108-109). Accordingly, for the market to operate, man - retaining his wording for consistency and convenience - must become detached from the product of his labour, and, since humanity is founded on productive activity, this detachment necessarily results in the type of disorientation he terms alienation. Marx also identified uncertainty and crisis as 
bedfellows of market exchange, a theme later more fully developed by Heidegger (1978). Uncertainty arises because parties to an exchange are never sure that what they receive will adequately compensate for their loss. In particular, the capitalist system, with its emphasis on efficiency improvements and change, provides no guarantee as to the utility of any commodity brought to the market, or that the worker will get his anticipated return for his labour. This uncertainty, in turn, may contribute to tension and foreboding in the marketplace.

\section{Sociology of Deviance}

Marx developed his theory to posit that alienation and uncertainty would be resolved through proletarian revolt. This, in hindsight, proved not to be the case. Yet Marx's insights endured and strongly influenced Durkheim, whose work spawned an extensive field of enquiry called the sociology of deviance. If Marx was optimistic about the prospects for de-alienation through revolution, Durkheim ((1897) 1970) was considerably less sanguine. In his theory of anomie he posited that deviant behaviour, rather than social upheaval, would be the outcome of the dysfunctions within capitalism ${ }^{1}$. This perspective was thus concerned with "deviant" phenomena such as suicide and crime. At the same time, Durkheim dwelt less on the exchange process itself and instead stressed that anomie is caused by structural contradictions in modern society. Despite these and subsequent observations, the sociology of deviance is today riddled with self-doubt, to the extent that Sumner has recently written its "obituary", classifying it as a "corpse", rather than a corpus, of knowledge (Sumner 1994). While an obituary may be premature, it is worth noting that, in essence, sociologists came to agree that the term 'normal' had lost true significance and that consequently any study of abnormality was logically incoherent. Also, as with psychiatry and psychoanalysis, the

\footnotetext{
${ }^{1}$ In contrast to both these positions, Baudrillard (Poster 1988) has suggested that in a postmodern world of hyper-exchange there is nothing left to be alienated from, and so the concept of alienation disappears through redundancy. Paradoxically, hyper-exchange destroys alienation and Marx's concept of human identity, which therefore has to be replaced by a notion of identity based on consumption rather than production: I shop, therefore I am.
} 
sociology of deviance was dominated by a view of deviance as "socially inadequate" and therefore concentrated on classification, control, and censure of the abnormal. In time, many sociologists became uncomfortable with this paternalistic, if not oppressive, approach. Here, they were partly influenced by the Surrealists, who provided an alternative understanding of madness to the mainstream view of 1930s psychiatry and psychoanalysis by celebrating the deviant as part of the normal rather than as a form of inadequacy.

\section{Nietzsche}

In The Birth of Tragedy, Friedrich Nietzsche ((1872) 1993) introduced the stimulating idea of the opposed forces of the active (the mad, Dionysiac tendency) and the reactive (the rational, Apolline tendency). In particular, he emphasised that the active, or potentially mad element, is foundational. Poignantly, this celebration of the extreme came from a man who himself later became insane, though the formulation had a beneficial and enduring effect on many of the literary, intellectual and artistic avant-garde of the twentieth century. In the context of the market, his work throws doubt upon the presumption of causality underlying much of the social theory inspired by Marx and Durkheim, namely that the market is primordial and that madness or extreme behaviour result from market activity. Instead, it indicates that the reverse causality is equally possible, providing a novel interpretation of the market as an outcome of madness. Furthermore, his ideas imply that extreme behaviour is a feature of all markets and not just modern capitalist markets, with which Marx, Durkheim, and later critical theorists such as Fromm (1956) and Habermas (1987), were almost exclusively concerned. As we noted above, Marx, and especially Durkheim, saw alienation and anomie primarily as the product of logical defects and structural instabilities associated with industrialisation and modernisation. At heart, "aberrant conduct" is viewed as a "symptom of dissociation between culturally defined aspirations and socially structured means" (Merton 1938 p. 674). However, Nietzsche's ideas suggest that madness is an innate characteristic and not just a by-product of structural contradictions. Moreover, our historical examples tend to support this view. 


\section{Anthropology and Ethnology}

In anthropology and ethnology we also find connections between market exchange and extremes or madness. The common etymological root of the words sanity and sanitation suggests that the separation of the normal from the mad is related to the division between the sacred from the profane, a topic that has been of keen interest to anthropologists (Douglas 1966) and, less frequently, to scholars of contemporary consumer behaviour, most notably in the Odyssey project of the 1980s (Belk et al. 1989). Indeed anthropology's raison d'être the study of the Other - is essentially an investigation of the limits or ends of the human condition, which is why the comparative study of boundary rituals, taboos, religious beliefs, the sacred and profane have always been central to the field. But sacred-profane and normalmad are not equivalent dimensions, and conflating them may be particularly inappropriate for our purposes. For example, gift-giving could be interpreted as a ritual in which objects are taken from the profane world of commerce and converted, through the ritual of decorative wrapping, into sacred gifts (Waits 1978). However, applying the normal-mad dimension to gift-giving yields no similar insights. Furthermore, gift-giving is not market exchange, a distinction that is well-known in anthropology and especially in the rich domain of economic anthropology.

Within this field, the work of Karl Polanyi and his student, George Dalton, is important, providing valuable views regarding the collocation of extreme behaviour and the market (Bohannan and Dalton 1962; Dalton 1968; Polanyi 1944; Polanyi et al. 1957). Polanyi emphasised that market exchange is only one particular form of transactional mode by which goods, services, land and labour are re-allocated. He identified and comprehensively analysed two other broad transactional modes or "patterns of integration": reciprocity (obligatory gift-giving between kin and friends) and redistribution (obligatory payments to a central authority which uses this wealth to support the community). Drawing on his deep knowledge of 'primitive economies', which were based on these systems, he was thus quick to dismiss Adam Smith's suggestion that markets, and man's propensity to barter, truck and exchange, were in some way axiomatic. Instead, he emphasised the unimportance of 
economic organisation in primitive society and the embeddedness of economic transactions in social and institutional structures (see also Granovetter (1985)). Moreover, he stressed that privileging the market is singularly inappropriate when interpreting the nature of primitive societies, which suggests that we may be investing too much weight in the commercial transactions depicted in our examples. Nonetheless, he took the socialist position that uncontrolled market exchange, based as it was on a view of man as a free, utilitarian "atom" rather than a societal animal, led to social disunity, destroying the underlying cohesion of communities founded on either reciprocity or redistribution. He thus agreed with Robert Owen's view that the laissez-faire system will necessarily lead to extremes and "will produce the most lamentable and permanent evils, unless its tendency be counteracted by legislative interference and direction" (Owen (1815) 1927 p. 121). Consequently, he supported government "interference" in the economy and the "welfare state", both of which he interpreted as an attempt to contain, control and normalise the market's inherent extremes.

\section{The Market as Crowd}

Elias Canetti's (1962) seminal study of crowds, and the extreme behaviour that characterises mobs, suggests that we might usefully see the market as a form of crowd. This shifts our attention away from society and the individual located within it to an intermediate construct the crowd - in which there is an a priori equality between all participants. Canetti lists a number of defining attributes of crowds, one of which reveals a possible explanation for the madness of the market. This is that crowds constantly fear disintegration, which means that they will accept any goal, no matter how irrational or extreme, to ensure their continued existence. He also described how the crowd, which like the market appears composed of multi-faceted elements, imposes a regularity which temporarily subjugates individuality to the mindlessness of the moment. However, Canetti's primary concern was with mobs, audiences and congregations, and consequently he over-emphasised homogeneity, which is hardly a feature of the markets that we have described (for further criticism see Rudé ((1964) 1995 p. 3)). In contrast, we have seen that markets are heterogeneous and diverse. 
Furthermore, one of his four defining attributes of crowds is that they "love density" (ibid. p. 29), which is hardly a defining attribute of markets.

\section{Explication}

All these literatures, in their various ways, provide different levels of insight into the peculiar co-occurrence of extreme or mad behaviour and commercial exchange. However, none of them comprehensively explains the form and range of extreme behaviour in the markets that we have described. This, we believe, is because each theory provides only a partial image of the market. Our aim, therefore, is to offer a more inclusive conceptualisation of the latter which adequately incorporates its extreme dimension and articulates the relationship with commercial exchange. We propose that the following six key features are essential aspects of the market: hybridity, illusion, agon, recursive transformation, elusive harmony, and tragedy.

\section{Hybridity}

As we saw from Canetti's work, the most significant distinction between a crowd and a market is that crowds are homogeneous while markets are heterogeneous. However, markets are not only heterogeneous, they are also hybrid places, a distinction that may warrant further explanation. Heterogeneity implies a mixture of two pure forms; hybridity, in contrast, is best understood as a heterodox fusion, rather than a mixture, of elements usually perceived as incompatible. Sand and salt mixed together produce a heterogeneous mixture, while oxygen and hydrogen fuse to form a hybrid - water. Latour (1993), in his study and characterisation of hybrid phenomena, has further proposed that, rather than beginning with poles of purity and imposing these on one's data, these poles are better understood as explanatory outcomes that are wrested out of the hybrid. This hybrid vision of the market might be described as pre-modern, for the pre-moderns, in contrast to the moderns, saw the world as saturated with combinations of divine, human and natural elements. "The native is a logical hoarder", writes Claude Lévi-Strauss; "he is forever tying the threads, unceasingly turning over all the aspects of reality, whether physical, social or 
mental" ((Lévi-Strauss (1962) 1966 p. 267) quoted in Latour (1993 p. 42))². This concept of hybridity also echoes the ideas of Stallybrass and White (1986), who studied carnivals and other sites of contradiction and transgression in the eighteenth and nineteenth centuries. In particular, it resonates through their valuable characterization of the market, which also clearly links commercial exchange and extreme behaviour:

At the market centre of polis we discover a commingling of categories usually kept separate and opposed: centre and periphery, inside and outside, stranger and local, commerce and festivity, high and low. In the marketplace pure and simple categories of thought find themselves perplexed and one-sided. Only hybrid notions are appropriate to such a hybrid place. (Stallybrass and White 1986 p. 27)

This interpenetration of opposing categories is vividly depicted in the markets we have examined, from the sacred and profane in Bruegel's painting, to the exchange and the extreme in Jesus's outburst in the temple. Moreover, the concept may also be extended to encompass hybridization of the body - "grotesque realism" - and hybridization of language the curses, profanities, and improprieties of the fair - that Bakhtin ((1968) 1984) documented in his interpretation of the world of carnival depicted by Rabelais.

\section{Illusion}

Nietzsche's writings suggest that market exchange may be understood as a manifestation of the surface order that the Apolline element seeks to impose on the Dionysiac foundation. This occurs because the operation of the market demands and emphasises quantification, rationalisation, abbreviation and control (Cooper 1992). While the common-sense view might see stable, bounded, finite information as a prerequisite for exchange, we can now contemplate an inverse relationship. In this, exchange can be seen as a mechanism that

\footnotetext{
${ }^{2}$ Interestingly, the 'postmodern' questioning of modernity and the simultaneous study of modernity's artefacts has created a new interest in hybrids, cyborgs and the inhuman (Callon and Law 1995; Haraway 1991; Kavanagh and Araujo 1995; Latour 1993).
} 
creates an illusion of stability, form, certainty and finiteness, which in turn forms part of the conscious protective shield around the primordial, chaotic, uncertain, infinite, mad, unconscious Dionysiac component. In other words, it is not so much that surprise must be suppressed for the market to operate, but rather that the market must operate to suppress surprise.

This illusion of stability is well illustrated in Edgar Degas' painting, from 1873, of the New Orleans Cotton Exchange (figure 3), one of a series he produced as a pictorial assessment of the business world. His A Cotton Office constitutes one of the most important visual representations of nineteenth-century capitalism (Brown 1993a p. 264), and, interestingly, it depicts a market that is apparently stable, sombre, refined and leisurely. This, however, is illusory. In a careful analysis of the work and its context, Brown (1993a), highlights the extremes that the representation of the market only barely masks. The picture shows a cotton office belonging to Degas' American uncle, which, despite the aura of restfulness and tranquillity, was actually going bankrupt when he was painting the piece. More broadly, world markets for cotton were shaken by an international stock market crash during the same year. Furthermore, the sobriety of the cotton office hides the extremes and inhumanity of the American South's cotton industry, built as it was on slavery and the slave trade with Africa.

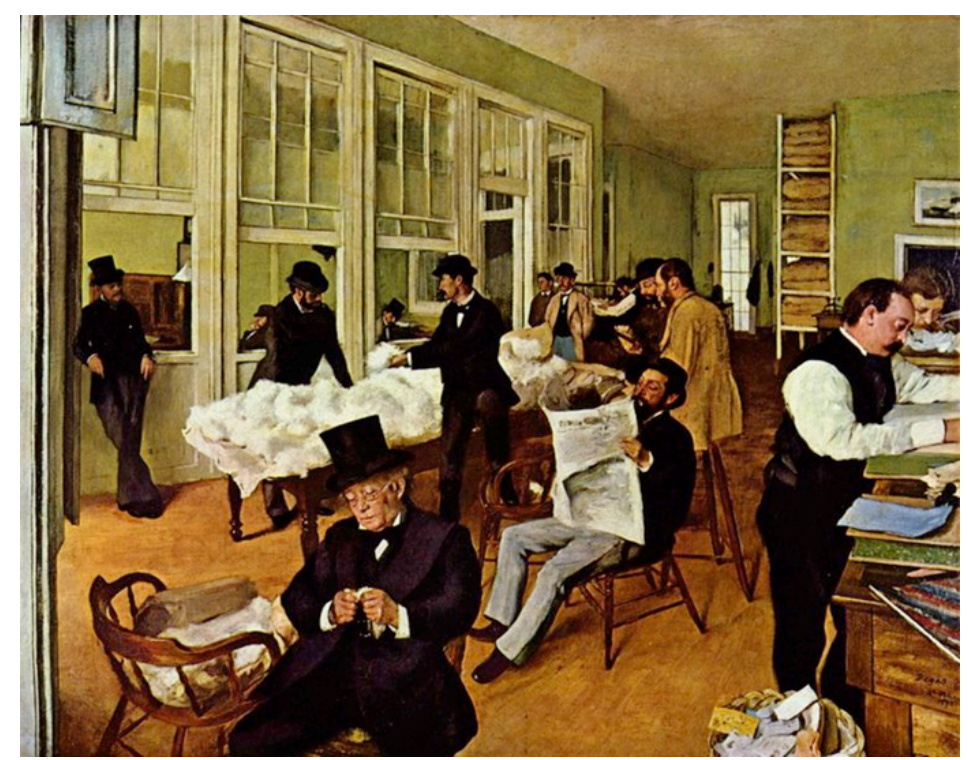

Figure 3. Edgar Degas, A Cotton Office, New Orleans (1873) Musée des Beaux Arts de Pau, with permission. 
Degas saw his painting as both a representation of the market and as a commodity in a market (the art market). Thus, the tableau was a reflection of the artist's own entrepreneurial venture and, significantly, this enterprise, like the cotton office it portrayed, also failed. Despite, or maybe because of, his involvement with the market, Degas was well-known for his blistering diatribes against the art market, commerce in general and the market-minded bourgeoisie in particular. This perspective is more obvious in another painting from the series, Sulking (occasionally called The Banker) which, according to Brown, is "an expression of modern psychological tensions owing something to the experiences of the Degas family business" (ibid. p. 278). Degas' own quip about the art market: 'there are successes that take the form of a panic', also shows his cognisance of the latter's extreme and irrational dimension, a feature that was particularly acute in the context in which he himself operated. Indeed elements in A Cotton Office suggest that Degas was subtly expressing some of these more aberrant market attributes in the painting. There is, for example, "perspectival disjunction" which led one critic to see in the picture "an uneasy image of his own prosaic world thrown out of joint" (ibid. p. 270). Allied to this is the work's exclusion of women, its "asymmetry", and the displacement of important signs, such as the safe and the framed art, to the picture's rightmost margin, all of which contribute to the painting's "unsettling" effect (ibid. p. 279).

Degas' A Cotton Office is thus an illusion of order. In addition, the exclusion of madness and inhumanity from the painting is itself a form of mis-representation or dissimulation. Dissimulation was also a dominant feature of the other markets that we described earlier: Bruegel's use of masks and other devices, the "creative exaggeration" of the twentieth century dog-fair, the overcharging for pigs ('as small as hedgehogs') and the 'shouts of lies, falsehood and exclamation' recounted in the Gaelic poem. More broadly, the concept of illusion is intrinsic to acting and the theatre, which have both provided helpful interpretive perspectives on organisational life (Höpfl 1995). 
The aforementioned Nietzschian view also emphasises the essentially agonistic character of the world in general and the market in particular. Nietzsche stressed that it is the abnormal, mad Dionysiac element that is legitimate, primary, and active. This thinker, especially in his later compositions, clearly saw the Dionysiac as primordial, implying that commercial exchange (the manifestation of the rational, Apolline tendency) must be seen as reactive and inferior. However, we prefer to see the market as a forum in which there is ongoing conflict between opposing categories, none of which should be regarded as essential or privileged. The market, for us, is a site of hybrid phenomena where categories meet, mingle and oppose one another. We use the term agon to represent this conflict. Agon means a struggle between two protagonists, and is etymologically close to agora, the Greek word for market, and to agonistic and antagonism which both indicate contest and opposition. It is also the source of the word agony which suggests human extremes of suffering and humiliation that are potentially the outcome of such aggression.

This strife is evident in our earlier textual and visual evidence: we may recall the disputes in Donnybrook fair (figure 2), the "fighting, striking and commotion" in the Gaelic poem, the challenge and race in Noinden Ulad, the Balinese cock-fights, the violence of Jesus in the temple, and the battle between carnival and Lent in Bruegel's painting (figure 1). Bruegel's piece also depicts a number of inversions - such as a woman taking the role of a horse which can also be interpreted as a manifestation of conflict. Bakhtin ((1968) 1984 p. 109) suggests that these inversions - such as a commoner acting as a king - are best seen as attempts by the lower orders to subvert and challenge the dominant social hierarchy. Other writers have also claimed that it is precisely because carnivals and fairs were sites of (potential) revolt that they were suppressed, especially in the nineteenth century (see Ó Maitiú (1995) for a description of the State and Church suppression of Donnybrook Fair, for example). An alternative, less utopian, view is that the carnival was a location where social protest was licensed and thus controlled (Sales 1983). The carnival also provided the emerging bourgeoisie in the nineteenth century with a depiction of a profane Other, and encoded "all that which the proper bourgeois must strive not to be in order to preserve a 
stable and 'correct' sense of self" (Stallybrass and White 1986 p. 178). Hence, it was both contained and sanctioned to ensure that this "sense of self" was maintained. Moreover, the lower social orders, while using the carnival as a forum for their particular form of social protest, were as likely, if not more likely, to use it to ritually re-assert their status above the most marginalised - such as women and minorities (ibid. p. 19).

Nietzsche's thesis is that the reactive Apolline or ordering tendency continually attempts to deny the existence of the active Dionysiac. In the context of the market, this means that commercial exchange seeks to confirm its dominance over the essentially mad character of the market (Deleuze 1983 pp. 40-42). Control, classification, and identification can each, then, be interpreted as reactions against the informal, self-referential, active that is innately beyond such exercises. This presents an alternative interpretation of many of the enterprises that we previously classed as deviant, such as gambling. Gambling might now be better viewed as a project or a technology in which uncertainty is rationalized and computed, a rational attempt to formalise the informal. We may thus explain why the Athenian agora was circumscribed by various centres of public administration erected over the course of time: the senate building (bouletreion), the kingly stoa or location of royal magistracy, and the prison in which Socrates died (Camp 1986). Similarly, our very attempt at classifying the mad could be interpreted as just another project to suppress the truly mad which is beyond understanding, beyond good and evil, beyond classification.

\section{Recursive Transformation}

The textual and visual evidence we have repeatedly returned to thus far illustrates a variety in both the form of commercial exchange and in the range of extreme behaviour exhibited. Bruegel and Degas both depicted quite different markets (one in the sixteenth and one in the nineteenth century) and significantly the form of dissimulation also differed in each case. What we now require is a thesis on the dynamic process by which both the form of exchange and extreme behaviour can be understood to change over time. 
A way forward is presented by the concept of recursion. This relates to how a change in one category folds back to change other categories in the market. There are two forms of recursion operating: immanent and extrinsic. Immanent recursion occurs solely through the cyclical and repetitive character of the market. The constant repetition of extreme or abnormal behaviour eventually blurs the distinction between the normal and the abnormal; what was previously extreme becomes merely unusual and finally normal, a phenomenon encapsulated in the Latin aphorism communis error facit ius (common error makes the law). Thus repetition of the extreme necessitates a redefinition of the abnormal as normal, providing the potential for new forms of madness or extreme behaviour to emerge.

Extrinsic recursion, in contrast to immanent recursion, is a dynamic change in the nature of one category caused by a change in another category, over and above simple transformation due to repetition. For example, we saw, in the early part of this century, profound alterations in the nature, location and scale of commercial exchange as capitalist markets replaced the medieval fair as the dominant locus of commerce. In this case, old, legitimised forms of madness are ostensibly marginalised as the spread of capitalist markets destroyed not only the fair but also the carnival and the particular and peculiar form of extreme behaviour of the carnivalesque. What is important, however, is that the extreme behaviour or madness was not eliminated. Instead it fragmented, transformed and migrated, re-emerging in new forms in different places. In the case of the nineteenth-century carnivalesque, its madness resurfaced in the Surrealist art of the period and in the hysteria first documented by the psychoanalysts of the early twentieth century (Stallybrass and White 1986 p. 181).

This recursive dynamic may also involve a spatial displacement. For example, Detroit was an important engine driving the expansion of the market in the early twentieth century, but its madness was transplanted to Chicago, where deviance of all sorts, ranging from gangsterism to prostitution, was rampant, and which was, according to Rudyard Kipling, "inhabited by savages". This transmutation and relocation of the extreme has not, however, disguised the essentially mad character of contemporary markets, and the connection is invariably re- 
discovered. For example, the Pop Art movement of the 1960s was an explicit attempt to depict or represent a large-scale capitalist market, similar to Degas' project during the late nineteenth century. Critically, and in contrast to Degas, Pop Art sought to reflect the banality and inhumanity - the madness - of the growing American consumer market. In keeping with this view of the market, this art-form produced banal, repetitive and apparently meaningless images ${ }^{3}$.

At the same time, other social mechanisms - the civilizing process referred to by Elias (1982) - also develop to counteract and control the extreme behaviour brought about by either immanent or extrinsic processes. Thus, side by side with the changes in the market and mania earlier in the present century, accounting systems developed in an attempt to restructure and circumscribe the individual (Miller and O'Leary 1987). Similarly, postmodern society is characterised by, not only madness, but also by a craving for control.

\section{Elusive Harmony}

In the previous section, the dynamic inter-relationship between exchange and extreme behaviour was articulated. Nevertheless, we do not seek to reduce the market to these two simple constructs, nor to imply some sort of Hegelian dialectic between them. The market, instead, consists of a heterogeneous mixture of hybrid categories, tending towards extremes, eluding any attempt to reduce it to a simple binary opposition or to a single unity.

\footnotetext{
${ }^{3}$ The Pop Art movement, and Andy Warhol's work in particular, also highlights some of the other features of the market that we have already addressed. For example, Warhol's paintings of soup cans conflated the divisions of high and low art, and, by mass-producing his own work, he also subverted the a priori categories of art and commerce. Thus, his work was a form of hybrid. Furthermore, like Degas, he was acutely aware of his own output as both a representation of a market and a commodity in a market. This double perspective provided more opportunities for inversions: for example, he delighted in subverting the law of supply and demand by re-issuing "limited" editions of his work. According to the law of the market this increase in supply should decrease the price of his work. However, this act of dissimulation only added to his notoriety, increasing both the demand for and the price of his products.
} 
This elusive attribute of the market does not, however, necessarily imply that it is chaotic or anarchic. Markets pulsate with a dynamic harmony. Here, we distinguish between the harmony of the market-place and the homogeneity of the crowd, as described by Canetti (1962). The market-place consists of heterogeneous elements that can vibrate and mingle, in harmony, and it is this dynamic interaction that provides the natural order of the market. Premodern fairs and carnivals provide good illustrations of this feature, since they were occasions when the unity of the primordial chaos was symbolically repeated and re-created. These assemblies sought to conjoin the Alpha and the Omega into a sacred unity allowing the temporary suspension of the profanity of human existence (Nowotny 1994 p. 103). This search for wholeness is further illustrated in the Irish word for fair, aonach, whose Old Irish root oenach is itself derived from the numeral oen 'one'.

The process by which unity or harmony is achieved deserves investigation because it is complex and counter-intuitive. Fundamental to the perception of unity is the process and act of separating; it is only through dividing that we can perceive the undivided whole. So the oenach can be seen as an attempt - through separating the finite and infinite, the ordered and chaotic, the market and madness - at re-creating a unity. The market, therefore, necessarily requires both the commingling and separation of categories to present the illusion of completeness. The unity is an illusion because it is both lost and unattainable. It is lost because it is an attempt to re-create the primordial oneness of the Alpha and the innocence of the Garden of Eden. It is unattainable because unity necessarily implies its duplication - one implies, indeed requires, two ${ }^{4}$.

\section{Tragedy}

\footnotetext{
${ }^{4}$ The vision of the market we have presented here echoes some of the ideas of Deleuze and Guattari and their notion of the "desiring machine" which is also "irreducible to any form of unity" (Deleuze and Guattari 1983 p. 42). Recently, Jordan (1995) has used their concept of "desiring machines" to present an interpretation of rave dances, which many see as a form of madness, as a "collective body".
} 
Our re-examination of the market has emphasised its antagonistic, dynamic, extreme and illusory nature. The confluence of each of these traits in the market also means that the latter may become a locus of tragedy. Most especially, tragedy may be born out of the conjuncture of fundamental opposing impulses, such as the Dionysiac and the Apolline. For example, our ninth-century saga indicates that the pre-Christian oenach was a site where the public and private domains, which were normally kept separate, were confused. This resulted in both the death of Macha and social turmoil in the society in question. In the biblical text, Jesus is the central tragic figure and again we find that the market is at the epicentre of his apocalyptic moment. Here, the tragedy is sparked by the confusion of the sacred and the profane in the temple. What is of interest is that this commingling creates tension, extreme behaviour, leading potentially to tragic schism.

Tragedies in the theatre provide an illuminating contrast to the tragedy inherent in the market-place. Tragedy, more than any other form of drama or representation, focuses on the very limits of the human condition, of extremes in suffering, elation, failure, agony and death. It is the site where the physical and the metaphysical meet - the early Greek tragedies were performed in honour of the god Dionysus - and where weird and hybrid characters and phenomena occur - such as horses turning cannibal in Macbeth. In this sense tragedies are eschatological since they, like the markets we have described, are the site in which limits, extremes and margins are potently articulated. This cosmic and eschatological dimension was developed to the full by Shakespeare in a set of masterful plays. These, like the market, are founded centrally on illusion. His tragedies centre on a powerful hero such as Lear or Macbeth, but this power is illusory because it masks a fatal flaw that eventually leads to failure and disaster. Similarly, human frailty is suggested in Bruegel's depiction of human characters at a small scale relative to the overwhelming expanse of the market-place they inhabit.

Tragedy is as likely to occur today in matters concerning the market as it demonstrably happened during times past. The current transformation of east-European societies from 
command to exchange-driven economies may be taken as a case in point. The market is either offered to, or perceived by, former communist states as a secular panacea for societal well-being. The model at issue is that of an orderly exchange whose rationality promises liberation from centralising tyranny. However, extremes likely to be found in the contemporary western market may not be revealed by its exponents or sufficiently appreciated by its recipients. A classic gap between perception and reality common to all tragic experience is thus in danger of emerging. This also provides the necessary ingredients for new forms of deranged behaviour to emerge, bewildering, as a result, whole nations. The latter is not a normative judgement on either western or eastern economic systems. Rather, it shows how thinking about the market opens up another window on the polarities of human existence. Tragedy, by expressing our limitations and the perceived extremes of humanity, is ultimately revealing and potentially redeeming. As Kermode has noted in his insightful distinction between myths and fictions, tragedy is "a fiction that inescapably involves an encounter with oneself, and the image of one's end" (1967 p. 39).

\section{The End in the Present}

The market's tragic dimension may possibly explain the deliberate separation of the festive (the mad) from the commercial in modern capitalist markets. This endeavour was especially worked on by the bourgeoisie of the nineteenth century who "laboured conceptually to reform the fair as either a rational, commercial, trading event or as a popular pleasure-ground" (Stallybrass and White 1986 p. 30, emphasis in original). Our study proposes, however, that such efforts at containing and suppressing the mad are futile, illusory and themselves doomed to fail. This belief is reinforced when we consider that madness is possibly the defining attribute of modernity in so far as the notion of progress necessarily celebrates deviance from past norms. Many factors suggest that madness is a dominant feature of contemporary markets, whether it be the craziness of Las Vegas or the dissimulation at the root of the Barings Bank collapse. Indeed, writers on management and marketing have regularly emphasised the importance of deviant, ludicrous behaviour, for instance March (1979) on the technology of foolishness, Peters $(1989 ; 1994)$ on chaos and crazy organisations, Pascale 
(1991) on conflict and "managing on the edge", or the current infatuation with disorganisation, chaos, catastrophe, and 'virtual' reality. Further back in time we find similar themes in old aphorisms such as Shaw's "all progress depends on the unreasonable man", Kierkegaard's "the instant of decision is madness", or Nietzsche's "to renounce false judgement would be to renounce life". Even more intriguing is the fact that the market has become a central feature of modernity. Indeed, modern intellectual history pivots around fundamental re-conceptualisations of the market: from Adam Smith's theory of the invisible hand, to Marx's profound insights into capitalist markets, to Baudrillard's writings on postmodern society, engulfed and consumed by the market.

Postmodernity is at once besotted by late capitalist markets and the extreme (Brown 1995; Featherstone 1988; Jameson 1991; Lyotard 1986; Poster 1988). Nietzsche's impact on the post-structuralists is particularly noteworthy, all of whom have embraced meaninglessness, the un-reasonable, the ludic, the libidinal, and the mad. Thus, Derrida's concept of différance carries with it the notion of deferred, different and absent meanings, implying a celebration of deviance, meaninglessness and madness. Nietzsche's notion of the Dionysiac resonates through Cooper and Burrell's comment that différance "is more than a theoretical concept", it is "a kind of prime energizer" (Cooper and Burrell 1988 p. 99). The post-structuralists' style of writing is further evidence of their infection. It is usually and deliberately at or beyond the limits of comprehension: de-ranged. More positively, the postmoderns, in centralising madness, can be seen as attempting to re-suture the artificial conceptual divisions that we have inherited from modernity (Latour 1993), and especially the illusory exclusion of madness from the market. Therefore, we can welcome much of the playful and nonsensical discourse of postmodernism, seeing it as part of a project of re-construction rather than of $d e$ construction.

\section{Conclusion}


In this chapter, we have sought to examine and understand the peculiar inter-relationship between commercial exchange and human extremes. Our study and methodology are founded on the opinion that the marketing academic can and should study markets, in their widest sense, unencumbered by normative or managerial agenda. We recognise that our effort at conceptualising the market may be doubly flawed: like the theories it draws on, it is partial and provisional, and the interpretation of 'primitive economies' is unavoidably prejudiced and ethnocentric. There is also the further danger that our montage of ninth- and eighteenth-century Gaelic assemblies, medieval markets and the economy of the United States will be viewed as legitimating superficial comparison. Nonetheless, we believe that there are major opportunities for future research along these lines. We look forward, for instance, to a much more rounded study of representations and depictions of markets in the historical record. Others might decide to focus on particular aspects of the range of extreme behaviour that pervade the exchange, such as the by now familiar catalogue of prostitution, wagering, dissimulation, inversions, noise, music, or drinking. Each of these is a substantial field of study in its own right, but marketing has largely ignored them as a collective: there is an absence of synthetic investigation describing the interweaving of these extremes in the market. It is appropriate and opportune that we examine such conditions, since societies tend to locate powerful symbolic repertoires at borders, margins and edges, as well as at accepted cores of the social body. In truth, therefore, our study of the End in the market is only a beginning.

\section{Acknowledgements}

Thanks to Luis Araujo, Stephen Brown, Joan Buckley, Bob Cooper, William Gallagher, Eileen Kavanagh, Diarmuid Kavanagh, Majella O'Leary, Don O'Sullivan, Brian Patterson, Terry O'Reilly, Colin Rynne, John Sheehan and particularly Sebastian Green for his constructive and supportive comments. 


\section{Biographical Notes}

Neil Buttimer was educated at University College, Cork, the Dublin Institute for Advanced Studies, and Harvard University, from which he holds a doctorate in Celtic Studies. His current research concentrates on literature and society in Early Ireland and on pre-Famine Gaelic Ireland. Donncha Kavanagh studied engineering in University College, Dublin and in the University of Missouri. He worked in construction, software development, project management and sales before joining the Department of Management and Marketing at University College, Cork. $\mathrm{He}$ is currently completing doctoral studies in Lancaster University under Luis Araujo and Geoff Easton. His research concentrates on industrial markets, socio-technical systems and organisation theory.

\section{References}

Bailey, J. and Vander Broek, L. D. (1992), Literary Forms in the New Testament, SPCK, London.

Bakhtin, M. ((1968) 1984), Rabelais and his World, Indiana University Press, Bloomington.

Barrell, J. (1980), The Dark Side of the Landscape: The Rural Poor in English Painting, Cambridge University Press, Cambridge.

Baudrillard, J. (1988), In the Shadow of the Silent Majorities, Semiotexte, New York.

Bauman, R. (1986), Story, Performance and Event, Cambridge University Press, Cambridge.

Belk, R. W., Wallendorf, M., et al. (1989), "The Sacred and the Profane in Consumer Behaviour: Theodicy on the Odyssey", Journal of Consumer Behaviour, Vol. 16(June), pp. 1-37.

Bohannan, P. and Dalton, G., eds (1962), Markets in Africa, Northwestern University Press, Evanston. 
Brown, M. R. (1993a), "An Entrepreneur in Spite of Himself: Edgar Degas and the Market", in T. L. Haskell and R. F. Teichgreber (eds), The Culture of the Market, Cambridge University Press, Cambridge, pp. 261-292.

Brown, S. (1993b), "Postmodernism ... The End of Marketing?", in D. Brownlie, et al. (eds), Rethinking Marketing, Warwick Business School Research Bureau, Coventry, pp. 112.

Brown, S. (1995), Postmodern Marketing, Routledge, London.

Brownlie, D. and Saren, M. (1992), "The Four Ps of the Marketing Concept: Prescriptive, Polemical, Permanent and Problematical", European Journal of Marketing, Vol. 26(4), pp. 34-47.

Brownlie, D. and Saren, M. (1995), "On the Commodification of Marketing Knowledge: Opening Themes", Journal of Marketing Management, Vol. 11(7), pp. 619-627.

Buttimer, C. G. (1992), "Tuairisc Amhailt Uí Iartáin: an Eighteenth-Century Poem on a Fair", Eighteenth-Century Ireland, Vol. 7, pp. 75-94.

Buttimer, C. G. (1994-95), "Longes mac nUislenn reconsidered", Éigse: A Journal of Irish Studies, Vol. 28, pp. 1-41.

Buttimer, C. G. (1995), "Noínden Ulad: Private and Public", unpublished paper presented at Tionól Conference, School of Celtic Studies, Dublin Institute for Advance Studies, 25 Nov.,

Buttimer, C. G. and Kavanagh, D. (1995), "Markets and Madness", in S. Brown, et al. (eds), Proceedings of the Marketing Eschatology Retreat, University of Ulster, Belfast, pp. $60-71$

Callon, M. and Law, J. (1995), "Agency and the Hybrid Collectif", South Atlantic Quarterly, Vol. 94(2), pp. 481-507.

Camp, J. M. (1986), The Athenian Agora: Excavations in the Heart of Classical Greece, Thames and Hudson, London.

Canetti, E. (1962), Crowds and Power, Gollancz, London. 
Cooper, R. (1992), "Formal Organization as Representation: Remote Control, Displacement and Abbreviation.", in M. Reed and M. Hughes (eds), Rethinking Organization, Sage, London, pp. 254-272.

Cooper, R. and Burrell, G. (1988), "Modernism, Postmodernism and Organisational Analysis: An Introduction", Organisation Studies, Vol. 9(1), pp. 91-112.

Dalton, G. (1968), "Introduction", in G. Dalton (ed.), Primitive, Archaic, and Modern Economies: Essays of Karl Polanyi, Beacon Press, Boston, pp. ix-liv.

Deleuze, G. (1983), Nietzsche and Philosophy, University of Minnesota Press, Minneapolis.

Deleuze, G. and Guattari, F. (1983), Anti-Oedipus: Capitalism and Schizophrenia, University of Minnesota Press, Minneapolis.

Douglas, M. (1966), Purity and Danger: An Analysis of the Concepts of Pollution and Taboo, Routledge, New York.

Durkheim, É. ((1897) 1970), Suicide, Routledge and Kegan Paul, London.

Elias, N. (1982), The Civilizing Process: State Formation and Civilization, Basil Blackwell, Oxford.

Featherstone, M., ed. (1988), Postmodernism, Sage, London.

Finley, M. I. (1982), Economy and Society in Ancient Greece, Viking Press, New York.

Foucault, M. (1967), Madness and Civilization, Routledge, Cambridge.

Fromm, E. (1956), The Sane Society, Routledge \& Kegan Paul, London.

Fukuyama, F. (1989), "The End of History?", The National Interest, Vol. 16(Summer), pp. 319.

Fullerton, R. A. (1987), "The Poverty of Ahistorical Analysis: Present Weakness and Future Cure in U.S. Marketing Thought", in A. F. Firat, et al. (eds), Philosophical and Radical Thought in Marketing, Lexington Books, Massachusetts, pp. 97-116.

Geertz, C. (1971), "Deep Play: Notes on the Balinese Cockfight", in C. Geertz (ed.), Myth, Symbol and Culture, W.W. Norton \& Company, New York, pp. 1-37.

Granovetter, M. (1985), "Economic Action and Social Structure: The Problems of Embeddedness", American Journal of Sociology, Vol. 91(3), pp. 481-510.

Habermas, J. (1987), The Philosophical Discourse of Modernity, Polity Press, Cambridge. 
Haraway, D. J. (1991), Simians, Cyborgs and Women: The Reinvention of Nature, Free Association Books, London.

Heidegger, M. (1978), Basic Writings from Being and Time (1927) to the Task of Thinking, Routledge and Kegan Paul, London.

Höpfl, H. (1995), "Performance and Customer Service: The Cultivation of Contempt", Studies in Culture, Organizations and Societies, Vol. 1(1), pp. 47-62.

Huizinga, J. (1955), Homo Ludens: a Study of the Play Element in Culture, The Beacon Press, Boston.

Hull, V. (1968), "Noínden Ulad: the Debility of the Ulidians", Celtica, Vol. 8, pp. 1-42.

Jameson, F. (1991), Postmodernism, or, the Cultural Logic of Late Capitalism, Verso, London.

Jordan, T. (1995), "Collective Bodies: Raving and the Politics of Gilles Deleuze and Felix Guattari", Body and Society, Vol. 1(1), pp. 125-144.

Kavanagh, D. (1994), "Hunt v Anderson: Round 16", European Journal of Marketing, Vol. 28(3), pp. 26-41.

Kavanagh, D. and Araujo, L. (1995), "Chronigami: Folding and Unfolding Time", Accounting, Management and Information Technologies, Vol. 5(2), pp. 103-121.

Kelly, F. (1988), A Guide to Early Irish Law, Dublin Institute for Advanced Studies, Dublin.

Kermode, F. (1967), The Sense of an Ending: Studies in the Theory of Fiction, Oxford U.P., Oxford.

Lash, S. and Urry, J. (1987), The End of Organized Capitalism, Polity, Cambridge.

Latour, B. (1993), We Have Never Been Modern, Harvester Wheatsheaf, New York.

Lévi-Strauss, C. ((1962) 1966), The Savage Mind, University of Chicago Press, Chicago.

Lyotard, J.-F. (1986), The Postmodern Condition: a Report on Knowledge, University of Manchester, Manchester.

March, J. G. and Olsen, J. P., eds (1979), Ambiguity and Choice in Organizations, Universitetsforlaget, Bergen.

Marx, K. ((1867) 1954), Capital: A Critical Analysis of Capitalist Production : Volume 1, Foreign Languages Publishing House, Moscow. 
Meadows, D. H., Meadows, D. L., et al. (1972), The Limits to Growth, Universe Books, New York.

Merton, R. K. (1938), "Social Structure and Anomie", American Sociological Review, Vol. 3, pp. 672-82.

Miller, P. and O'Leary, T. (1987), "Accounting and the Construction of the Governable Person", Accounting, Organizations and Society, Vol. 12(3), pp. 235-266.

Nietzsche, F. ((1872) 1993), The Birth of Tragedy, Penguin Books, London.

Nowotny, H. (1994), Time : The Modern and Postmodern Experience, Polity Press, Oxford.

Ó Maitiú, S. (1995), The Humours of Donnybrook: Dublin's Famous Fair and its Suppression, Irish Academic Press, Dublin.

Otis, L. L. (1985), Prostitution in Medieval Society: the History of an Urban Institution in Languedoc, The University of Chicago Press, Chicago.

Owen, R. ((1815) 1927), A New View of Society and Other Writings, Everyman, New York.

Pascale, R. T. (1991), Managing on the Edge: How Successful Companies use Conflict to Stay Ahead., Penguin, London.

Peters, T. (1989), Thriving on Chaos, Pan Books Ltd., London.

Peters, T. (1994), The Tom Peters Seminar: Crazy Times Call for Crazy Organizations, Macmillan, London.

Polanyi, K. (1944), The Great Transformation, Rinehart, New York.

Polanyi, K., Arensberg, C. M., et al., eds (1957), Trade and Market in the Early Empires : Economies in History and Theory, Free Press, Glencoe.

Poster, M., eds (1988), Jean Baudrillard: Selected Writings, Polity Press, Cambridge.

Powell, M. A. (1990), What is Narrative Criticism? A New Approach to the Bible, SPCK, London.

Rifkin, J. (1995), The End of Work : the Decline of the Global Labor Force and the Dawn of the Post-Market Era, Jeremy P. Tarcher, New York.

Rudé, G. ((1964) 1995), The Crowd in History, Serif, London.

Sales, R. (1983), English Literature in History 1780-1830: Pastoral and Politics, Hutchinson, London. 
Sass, L. A. (1992), Madness and Modernism, Harvard University Press, Cambridge.

Stallybrass, P. and White, A. (1986), The Politics and Poetics of Transgression, Methuen, London.

Steiner, G. (1984), Antigones: The Antigone Myth in Western Literature, Art and Thought, Clarendon Press, Oxford.

Suchaux, G. and Pastoureau, M. (1994), The Bible and the Saints, Flammarion, New York.

Sumner, C. (1994), The Sociology of Deviance, Open University Press, Buckingham.

Thurneysen, R. (1921), Die irische Helden - und Königsage bis zum siebzehnten Jahrhundert, Max Niemeyer, Halle.

Touraine, A. (1974), The Post-Industrial Society, Wildwood Press, New York.

Waits, W. B. (1978), The Many-Faced Custom: Christmas Gift-Giving in America, 19001940, unpublished dissertation, History Department, Rutgers University, New Brunswick , NJ.

\section{Figures}

